\title{
Personal values as predictors of entrepreneurial intentions of university students
}

\begin{abstract}
Considering entrepreneurship as a set of actions performed by a subject, and behavior one of the main predictors of actions, this work presents a study based on the Theory of Human Values, that aims to analyze the influence of personal values on entrepreneurial intention of university students; understanding as well the personal values as cognitive characteristics that explain the attitudes of a subject towards entrepreneurship, the hypotheses of this work establish a positive relation between values associated to individualism and the entrepreneurial intention as well as a negative relation between values associated to collectivism and the entrepreneurial intention of university students. For this, a sample of 488 undergraduate students from the University of Guadalajara in Mexico is used and statistical analysis is performed through the SPSS software. Using a quantitative methodology, an exploratory factorial analysis and a linear regression model are performed to calculate the predictive capacity of the different types of personal values on the entrepreneurial intention of students at the University previously mentioned. Personal values associated to individualism prove to be highly related to entrepreneurial intentions while those related to collectivism show low or null effect. Some exceptions are discussed and lead to future lines of research regarding different types of entrepreneurship.
\end{abstract}

Keywords: Entrepreneurial intention; personal values; university students; collectivism; individualism

Corresponding author: e- a.campos@ cucea.udg.mx

Received April 17, 2020 - Accepted March 11, 2021

This is an Open Access article distributed under the terms of the Creative Commons Attribution-Non-Commercial-No Derivatives License (http://creativecommons.org/licenses/by-nc-nd/4.0/), which permits non-comercial re-use and distribution, provided the original work is properly cited, and is not altered or transformed in any way. 


\section{Introduction}

Abundant research has been conducted in recent years regarding the phenomenon of entrepreneurship. The variety of scopes and issues related to this topic, cover from the macroeconomic and economic development of regions around the world (Clemmens and Heinemann 2006; Quadrini, 2009; Parker 2018), all the way to the very particular studies regarding the process of business creation or even more specific, the entrepreneur as a subject itself (McKenna 1996; Hebert and Link 2006; Mukherjee 2016)

In this sense, this research aims to evaluate the influence of personal values on the entrepreneurial intention of university students, analyzing a sample of 488 students at the Scholl of Business of the University of Guadalajara, using statistical techniques with a correlational scope.

Analyzing the personal characteristics of university students related to entrepreneurial intentions and identifying which of these characteristics have better explanation capacities on entrepreneurial attitudes, allows educational policy and decision makers to understand in a deeper way how new generations perceive entrepreneurship as a path to the future or even an option to join as a professional career.

In order to adequately understand what this research is intended to evaluate, this work starts presenting a literature review of the main theories and concepts related to entrepreneurship and the entrepreneurial subject, entrepreneurial intention, personal values, the relationship between values, attitudes and behavior, among others. This literature review is done for two purposes; first, to know the state of the art of the topic of personal values and the influence on entrepreneurial intention at the present time and to discard any possibility of duplicating the 
study on the phenomenon in this particular context; second, to give theoretical support and literature base to the statement of the hypotheses.

According to this, the objective of this research is to evaluate the role of personal values as determinants of the entrepreneurial intention in university students. Likewise, it is intended to test whether the various classifications of personal values, may positively or negatively influence the entrepreneurial intention of the university students who were chosen as a sample; finally, the results of this experiment will be compared with results of similar experiments in different contexts.

This article provides a theoretical framework about the elements of the study such as entrepreneurial intention, personal values analyzed within the field of entrepreneurship, the classification of personal values according to the individualism-collectivism criteria and the entrepreneurial attitude.

Another section explains the methodology followed to conduct the study followed by the analysis of results. Finally, a discussion and conclusions section is presented.

\section{Theoretical framework}

\subsection{Entrepreneurial Intention}

The phenomenon of entrepreneurship can emerge from different scenarios: Two of the most mentioned in literature are, on one hand, the scenario where the subject recognizes an opportunity and finds the best conditions to start a project, and on the other hand, the scenario where the need pushes the individual to start a business as soon as possible. 
The factors associated with the opportunity recognition are represented by the environment, such as universities, government and other actors that promote entrepreneurship, while the factors related to the need are represented by situations that are not favorable for people such job dissatisfaction or unemployment (Mueller and Thomas 2001). However, some of these factors occur in situations that are external to a person, so identifying and exploiting business opportunities depends directly on the cognitive aspects of the entrepreneur, aspects that are mainly explained by skills and motivations, that means, there could be an entire ecosystem of entrepreneurship well defined to facilitate the entrepreneurial processes, however, the decision of an individual to undertake or not depends directly on the subject.

Given this panorama, the generation of knowledge about the cognitive aspect of the entrepreneur has been incorporated into the field of study of entrepreneurship, in order to obtain a much deeper understanding about the phenomenon of entrepreneurship, which has been called Entrepreneurial Intention (EI).

Soria, Zuñiga, and Ruiz (2016) define EI as the self-recognition of the security that an individual can present in creating a business; it is also shown as the best predictor of certain behavior in the future, which are determined by the desires, motivations, and viability of exploiting a market opportunity (Romero and Milone 2016).

The models that explain EI are a key factor in the action of starting or not starting a business, since it encompasses cognitive processes, such as intentions that act as sources of balance among other external factors, for example, social, cultural variables, demographic, among others (Chattopadhyay and Ghosh 2008). 
The development of an EI depends on the integration of personal and contextual guide and explain behavior of people. Contextual factors are the subjective norm, the perception of opportunities and the limitation of resources. Both contribute significantly to the construction of an EI. It is for this reason that EI models demonstrate a person's ability to understand and realize the process of generation of new businesses (Bird 1988; Krueger, Reily and Carsrud 2000).

Among the great variety of personal characteristics that may explain the entrepreneurial intention of an individual, personal values have gained importance in the last decade (Jaén, Moriano and Liñán 2013; Campos 2018; Kruse et al. 2019; Hueso and Liñan 2020) and this has to do with the recognition of the fundamental role of personal values in the prediction of attitudes and hence of behavior.

\subsection{Personal values in the field of entrepreneurship}

Entrepreneurship is a phenomenon that has increased in importance for researchers of the last couple of decades. After several years of research in this field, scientific texts still present difficulties in defining some basic terms such as entrepreneur and entrepreneurship (Gartner 1988; Bygrave and Hofer 1992; Rosa and Bowes 1993).

Entrepreneurship cannot be considered as an isolated action, on the contrary, it must be seen as a process that involves different scenarios, which are not merely economic in nature but emanate from the social context that shapes and shapes business results (Anderson and Jack 2002). Thus, the entrepreneurial process is carried out by people, and the study of those people who carry out this type of activity is as important as the study of the entrepreneurial process 
itself; it is not possible to understand the entrepreneurial process without observing and understanding the people who carry it out.

Various aspects of the personal characteristics that define the entrepreneur have been studied in academic texts; characteristics such as skills, talent, and knowledge that influence the possible success or failure of new entrepreneurship projects (Brandstätter 2011; Hormiga, Campos and Valls 2011; Širec and Močnik 2012; Ahmadkhani et al. 2013; Xie 2014), but also, personal characteristics such as personal values have been appearing more and more in recent literature.

Personal values are recognized as some of the most important cognitive characteristics of humans due to their prevalence over time. It is well accepted in the scientific community that personal values are difficult to change easily in a short time lapse, in other words, they maintain relatively stable overtime (Dolan, Garcia and Richley 2006, 28)

In the field of entrepreneurship, personal values have often been mentioned as a secondary cognitive aspects explaining certain factors. Personal values, related to entrepreneurship started to appear in the 1970's, when Hornaday and Aboud (1971) identified personal values such as achievement, independence and leadership, as characteristics more visible in successful entrepreneurs that in other subjects. Different authors have mentioned similar personal values as a part of a set of motivational factors driving entrepreneurship in high-tech industry, they reported no significant difference between personal characteristics of high-tech entrepreneurs and any other entrepreneur.

However, it is not until the decade of the 1990s that personal values appeared as the main independent variable explaining some factor related to the entrepreneurial behavior, attitude, 
intention, or even some other variable embedded in the entrepreneurial process. (Fagenson 1993; Morris, Avila and Allen 1993; Hussin 1997; Lipset 2000)

In the last two decades, the research relating personal values and entrepreneurship has raised as an important field of study. During these two last decades, personal values finally became a worth-to-explore topic in the field of business creation. From 2000 to the date, we found several works analyzing how these characteristics explain different aspects of the entrepreneurial process. And this time is also where we start to find scientific work on the role of personal values in entrepreneurial attitudes, motivations or intentions (Brice 2004; Liñan,2008; Liñan and Chen 2009; Zhao, Seibert and Limpkin 2010; Fayolle, Liñan and Moriano 2014; Liñan, Moriano and Jaén 2016; Campos 2018).

\subsection{Individualism vs collectivism in entrepreneurship}

In academic business research, the topic of personal values has generally been related to work. Some studies have tried to demonstrate the relationship between personal values and, for example, the feelings of satisfaction or motivation at work.

Despite this, there is little research regarding the role played by personal values of entrepreneurs in the entire process of creation and the reach for survival of a new company (Amit et al. 2001). Holland and Shepherd (2013) make important contributions to this stream of literature by exploring how an entrepreneur's personal values influence the way in which he decides to persist in his decision to seize an opportunity. Using Schwartz's (1992) theory of values, these authors investigate individual differences in how values influence persistent business decisions and find that personal values help explain the variation in emphasis individuals place in their different decision criteria. The authors capture entrepreneurial decisions in real-time and 
examine how individual and contextual differences are related to variations in decision making, concluding that entrepreneur persistence in decision making can be attributed to differences in their values.

On the other hand, Tomczyk, Lee and Winslow (2013) proved that the performance of high growth companies is related to the values of the entrepreneur. These authors studied entrepreneurs highly successful and demonstrated the impact of caring for other values on company performance.

A highly studied relationship is one that exists between individualist-collectivist values and the tendency to be an entrepreneur. Some personal values respond to individual interests while others respond to collective interests (Ros and Grad 1991). The latter, it is argued, "implies [n] the subordination of personal interests to the objectives of the largest working group, an emphasis on exchange, cooperation and harmony, a concern for the well-being of the group and hostility towards external members" (Morris and Davis 1994, 598). Thus, it is postulated that the values that serve individual interests are the antithesis of those that serve the collective interest (Schwartz 1992).

In Table 1, the values in this study are classified according to the different categories of the analyzed values. These values are those that are related in more aspects with the entrepreneurial belief. The first four values are those located in the group of values that are largely associated with the beliefs of the entrepreneur. On the contrary, security is the most contrary value to the beliefs related to the entrepreneur. Finally, universalism and benevolence are those values related to new management paradigms, such as collaborative management, and are chosen to understand whether or not entrepreneurial attitudes are related. 
TABLE 1. Classification of values related to entrepreneurial attitude

\begin{tabular}{|c|c|c|c|}
\hline $\begin{array}{l}\text { Type of } \\
\text { motivation }\end{array}$ & Description of the indicator & $\begin{array}{l}\text { Type of reason } \\
\text { (Schwartz and } \\
\text { Bohenke 2004) }\end{array}$ & $\begin{array}{l}\text { Type of } \\
\text { orientation } \\
\text { (Gouvieia 2003) }\end{array}$ \\
\hline Self-direction & $\begin{array}{l}\text { Independence in decision-making. } \\
\text { Setting own goals and ways of behaving. } \\
\text { Do what it takes to develop and spread } \\
\text { your own ideas }\end{array}$ & $\begin{array}{l}\text { Openness to } \\
\text { change }\end{array}$ & $\begin{array}{l}\text { Individualism } \\
\text { (Personal) }\end{array}$ \\
\hline Power & $\begin{array}{l}\text { Leadership and recognition of other team } \\
\text { members. }\end{array}$ & Self-enhancement & $\begin{array}{l}\text { Individualism } \\
\text { (Personal) }\end{array}$ \\
\hline $\begin{array}{l}\text { Achievement } \\
\text { (economic) }\end{array}$ & $\begin{array}{l}\text { Achievement of economic goals and } \\
\text { desire to improve the current economic } \\
\text { situation }\end{array}$ & Self-enhancement & $\begin{array}{l}\text { Individualism } \\
\text { (Personal) }\end{array}$ \\
\hline Stimulation & $\begin{array}{l}\text { Inspired by challenges, satisfied by } \\
\text { working as a team to the limit of abilities } \\
\text { and working at all times with enthusiasm }\end{array}$ & $\begin{array}{l}\text { Openness } \\
\text { change }\end{array}$ & $\begin{array}{l}\text { Individualism } \\
\text { (Personal) }\end{array}$ \\
\hline Hedonism & $\begin{array}{l}\text { Pleasure and sense of gratification for } \\
\text { oneself }\end{array}$ & Self-enhancement & $\begin{array}{l}\text { Individualism } \\
\text { (Personal) }\end{array}$ \\
\hline Security & $\begin{array}{l}\text { Carry out daily activities in a safe } \\
\text { environment, free from any type of } \\
\text { threat. }\end{array}$ & Conservation & Central \\
\hline Universalism & $\begin{array}{l}\text { A concern for the economic and political } \\
\text { situation of the community, a } \\
\text { commitment to the common good. }\end{array}$ & $\begin{array}{l}\text { Self- } \\
\text { transcendence }\end{array}$ & $\begin{array}{l}\text { Collectivism } \\
\text { (Social) }\end{array}$ \\
\hline Benevolence & $\begin{array}{l}\text { Maintain good relationships with those } \\
\text { who care and are in frequent contact. }\end{array}$ & $\begin{array}{l}\text { Self- } \\
\text { transcendence }\end{array}$ & $\begin{array}{l}\text { Collectivism } \\
\text { (Social) }\end{array}$ \\
\hline Conformity & $\begin{array}{l}\text { Restraint of actions, inclinations and } \\
\text { impulses likely to harm others and } \\
\text { violate social norms }\end{array}$ & Conservation & $\begin{array}{l}\text { Collectivism } \\
\text { (Social) }\end{array}$ \\
\hline Tradition & $\begin{array}{l}\text { Respect, commitment and acceptance of } \\
\text { customs, culture and ideas or religion } \\
\text { provide, }\end{array}$ & Conservation & $\begin{array}{l}\text { Collectivism } \\
\text { (Social) }\end{array}$ \\
\hline
\end{tabular}

Source: Own elaboration with data from Gouveia (2003); Schwartz and Bohenke (1992); Ros and Grad (1991).

Following this insights, the hypotheses proposed for this work are presents next: 
H1.- Personal values associated to individualism are positively related to entrepreneurial intention

H1a. Personal value self-direction influence positively the entrepreneurial intention of university students

H1b. Personal value power influence positively the entrepreneurial intention of university students

H1c. Personal value achievement influence positively the entrepreneurial intention of university students

H1d. Personal value hedonism influence positively the entrepreneurial intention of university students

H1e. Personal value stimulation influence positively the entrepreneurial intention of university students

H2.- Personal values associated to collectivism are negatively elated to entrepreneurial intention

H2a. Personal value security influence negatively the entrepreneurial intention of university students

$\mathrm{H} 2 \mathrm{~b}$ Personal value universalism influence negatively the entrepreneurial intention of university students

$\mathrm{H} 2 \mathrm{c}$. Personal value tradition influence negatively the entrepreneurial intention of university students 
$\mathrm{H} 2 \mathrm{~d}$. Personal value benevolence influence negatively the entrepreneurial intention of university students

H2e. Personal value conformity influence negatively the entrepreneurial intention of university students

\section{Methodology}

As previously established, the main objective of this work is to analyze the influence that the presence of certain personal values of students at the School of Business (CUCEA) at the University of Guadalajara has on their intention to undertake; a quantitative methodology with the correlational scope is used to know the causal relation between the variables established in the hypotheses.

To obtain data, a Likert scale questionnaire was designed, with two main components that present, on the one hand, scenarios associated with the meaning and presence of certain personal values in students according to the classification and definition of the types of values proposed by Schwartz and Boehnke (2004) and, on the other hand, the entrepreneurial intention scale designed by Liñan and Chen (2009).

The instrument consists of 40 items on a Likert scale from 1 to 7 where 1 corresponds to a level of "totally disagree" and 7 corresponds to the level of "totally agree" with the scenarios proposed. The instrument was applied to 488 students of the different degrees from CUCEA of the University of Guadalajara during the month of July 2019. This University Center attends a total of 17,980 undergraduate students. All of them attend majors related to economic and management sciences such as accounting, management, human resources, marketing, 
international business, finance, economy. The sample was chosen randomly, with the necessary awareness that there were no duplicate responses by the same student.

Once the data was obtained, the database was captured and prepared in a spreadsheet and later converted into a data-sheet in the SPSS statistical software. Subsequently, exploratory factor analysis was performed and the reliability indexes of the scales obtained in the reduction of dimensions were calculated; as well as a linear regression model to establish the predictive capabilities of the independent variables (personal values) on the dependent variable (entrepreneurial intention).

Finally, a discussion of the results is carried out and conclusions are established.

\section{Analysis of results}

Factor analysis is performed, which reflects a KMO sample adequacy indicator of .855 which is considered to be at a significant level. In the same factor analysis, the explained variance table was obtained, where it turns out that the data collected explains up to 63 percent of the phenomenon. (see Table 2).

The rotating components matrix of this same factor analysis shows the grouping of variables into factors corresponding to the different factors that make up the instrument. The grouping agrees with the theoretical foundation, that is, the variables grouped in the different factors according to the matrix of rotated components correspond to the meanings of each of the types of vàlues according to the literature (see Table 2). 
TABLE 2. Factorial analysis (rotated component matrix)

\begin{tabular}{|c|c|c|c|c|c|c|c|c|c|c|}
\hline & \multicolumn{10}{|c|}{ Component } \\
\hline & 1 & 2 & 3 & 4 & 5 & 6 & 7 & 8 & 9 & 10 \\
\hline Selfdirection 1 & & & & & .659 & & & & & \\
\hline Selfdirection2 & & & & & .583 & & & & & \\
\hline Selfdirection 3 & & & & & .717 & & & & & \\
\hline Selfdirection4 & & & & & .663 & & & & & \\
\hline Universal1 & & & 580 & & & & & & & \\
\hline Universal2 & & & 650 & & & & & & & \\
\hline Universal3 & & & 814 & & & & & & & \\
\hline Universal4 & & & 747 & & & & & & & \\
\hline Tradition 1 & & & & .485 & & & & & & \\
\hline Tradition 2 & & & & .581 & & & & & & \\
\hline Tradition3 & & & & .579 & & & & & & \\
\hline Tradition4 & & & & .704 & & & & & & \\
\hline Tradition5 & & & & .488 & & & & & & \\
\hline Stimulation1 & & & & & & & & .481 & & \\
\hline Stimulation2 & & & & & & & & .598 & & \\
\hline Stimulation3 & & & & & & & & .816 & & \\
\hline Hedonism1 & & & & & & & & & .637 & \\
\hline Hedonism2 & & & & & & & & & .654 & \\
\hline Power1 & & .773 & & & & & & & & \\
\hline Power2 & & .767 & & & & & & & & \\
\hline Power3 & & .734 & & & & & & & & \\
\hline Power4 & & .643 & & & & & & & & \\
\hline Power5 & & .581 & & & & & & & & \\
\hline Security1 & & & & & & & .793 & & & \\
\hline Security2 & & & & & & & .768 & & & \\
\hline Security 3 & & & & & & & .415 & & & \\
\hline Conformity1 & & & & & & & & & & .618 \\
\hline Conformity2 & & & & & & & & & & .587 \\
\hline Benevolence1 & .713 & & & & & & & & & \\
\hline Benevolence2 & .777 & & & & & & & & & \\
\hline Benevolence3 & .754 & & & & & & & & & \\
\hline Benevolence4 & .726 & & & & & & & & & \\
\hline Achievement1 & & & & & & .862 & & & & \\
\hline Achievement 2 & & & & & & .849 & & & & \\
\hline Achievement 3 & & & & & & .655 & & & & \\
\hline & & & ation & 111 & 1111 & $\begin{array}{l}\text { ol cor } \\
\text { ormal }\end{array}$ & $\begin{array}{l}\text { onen } \\
\text { tion }\end{array}$ & $\begin{array}{l}\text { alysis. } \\
\text { Kaise }\end{array}$ & & \\
\hline & & & .11 & tatio & s con & ged w & in $10 \mathrm{i}$ & ations. & & \\
\hline
\end{tabular}

Source: Own elaboration. 
Once the composition of the factors was obtained, the reliability analysis was carried out using Cronbach's alpha, which is why the results shown in Table 3 were obtained:

TABLE 3. Cronbach Alfa for scales obtained

\begin{tabular}{|c|c|c|c|}
\hline \multicolumn{4}{|c|}{ Dimension reduction of personal values } \\
\hline Name & Number of items & $\%$ variance & Cronbach's Alpha \\
\hline Self-direction & 4 & 9.28 & .695 \\
\hline Universalism & 4 & 8.72 & .722 \\
\hline Tradition & 5 & 7.01 & .760 \\
\hline Stimulation & 3 & 6.72 & .574 \\
\hline Hedonism & 2 & 6.60 & .506 \\
\hline Power & 5 & 6.25 & .791 \\
\hline Security & 3 & 5.59 & .714 \\
\hline Compliance & 2 & 4.79 & .684 \\
\hline Benevolence & 4 & 4.47 & .814 \\
\hline Achievement & 3 & 3.53 & .775 \\
\hline Total & 35 & 62.96 & \\
\hline KMO & .855 & & \\
\hline Significance & .000 & & \\
\hline
\end{tabular}

Source: Own elaboration.

As observed in Table 3, it is found that eight out of the ten scales of the factors obtained present acceptable reliability indices. It is recognized that in two factors, stimulation and hedonism, the reliability indicators do not reach an optimal level, however, previous works have found the same limitation (Campos 2018; Gorgievsky, Ascalon and Stephan 2011; Schwartz et al. 2001)

Correlation matrix for the components extracted is presented next in Table 4. 
TABLE 4. Correlation matrix

\begin{tabular}{|c|c|c|c|c|c|c|c|c|c|c|c|}
\hline & & $\begin{array}{r}\text { Bene- } \\
\text { volence }\end{array}$ & Power & $\begin{array}{r}\text { Self- } \\
\text { direction }\end{array}$ & $\begin{array}{r}\text { Univer- } \\
\text { salism }\end{array}$ & $\begin{array}{r}\text { Achieve- } \\
\text { ment }\end{array}$ & $\begin{array}{r}\text { Stimu- } \\
\text { lation }\end{array}$ & $\begin{array}{r}\text { Tradi- } \\
\text { tion }\end{array}$ & $\begin{array}{r}\text { Secu- } \\
\text { rity }\end{array}$ & $\begin{array}{r}\text { Hedo- } \\
\text { nism }\end{array}$ & $\begin{array}{r}\text { Confor- } \\
\text { mity }\end{array}$ \\
\hline \multirow{3}{*}{$\begin{array}{l}\text { Bene- } \\
\text { volence }\end{array}$} & Corr & 1 & $.383^{* *}$ & $.503^{* *}$ & $321^{* *}$ & $.273^{* *}$ & $.440^{* * *}$ & $.547^{* *}$ & $.355^{* *}$ & $.379^{* *}$ & $.195^{* *}$ \\
\hline & Sig & & .000 & .000 & .000 & .000 & .000 & .000 & .000 & .000 & .000 \\
\hline & $\mathrm{N}$ & 481 & 474 & 480 & 476 & 479 & 480 & 479 & 478 & 473 & 476 \\
\hline \multirow[t]{3}{*}{ Power } & Corr & $.383^{* * *}$ & 1 & $344^{* *}$ & $200^{* * *}$ & $.283^{* *}$ & $.422^{* *}$ & $.315^{* *}$ & $.204^{* * *}$ & $.121^{* *}$ & $.149^{* * *}$ \\
\hline & Sig & .000 & & .000 & .000 & .000 & .000 & .000 & .000 & .009 & .001 \\
\hline & $\mathrm{N}$ & 474 & 475 & 474 & 470 & 472 & 474 & 473 & 471 & 468 & 471 \\
\hline \multirow{3}{*}{$\begin{array}{l}\text { Self- } \\
\text { direction }\end{array}$} & Corr & $.503^{* *}$ & $344^{* *}$ & 1 & $393^{* *}$ & $263^{* *}$ & $394^{* * *}$ & $.384^{* *}$ & $.226^{* *}$ & $.236^{* *}$ & $.121^{* * *}$ \\
\hline & Sig & .000 & .000 & & .000 & .000 & .000 & .000 & .000 & .000 & .008 \\
\hline & $\mathrm{N}$ & 480 & 474 & 488 & 482 & 479 & 481 & 484 & 482 & 478 & 480 \\
\hline \multirow{3}{*}{$\begin{array}{l}\text { Univer- } \\
\text { salism }\end{array}$} & Corr & $321^{* *}$ & $200^{* * *}$ & $393^{* *}$ & 1 & $.225^{* *}$ & $.343^{* * *}$ & $268^{* * *}$ & $.111^{*}$ & $177^{* *}$ & .051 \\
\hline & Sig & .000 & .000 & .000 & & .000 & .000 & . 000 & .015 & . 000 & .269 \\
\hline & $\mathrm{N}$ & 476 & 470 & 482 & 483 & 475 & 477 & 479 & 477 & 473 & 476 \\
\hline \multirow{3}{*}{$\begin{array}{l}\text { Achieve- } \\
\text { ment }\end{array}$} & Corr & $.273^{* *}$ & $.283^{* *}$ & $.263^{* *}$ & $.225^{* *}$ & 1 & $.363^{* *}$ & $.133^{* *}$ & .057 & $.186^{* *}$ & -.007 \\
\hline & Sig & .000 & .000 & .000 & .000 & & .000 & .004 & .214 & .000 & .871 \\
\hline & $\mathrm{N}$ & 479 & 472 & 479 & 475 & 480 & 479 & 477 & 476 & 471 & 474 \\
\hline \multirow{3}{*}{$\begin{array}{l}\text { Stimu- } \\
\text { lation }\end{array}$} & Corr & $.440^{* *}$ & $.422^{* *}$ & $.394^{* *}$ & $343^{* *}$ & $.363^{* *}$ & 1 & $.329^{* *}$ & $.124^{* *}$ & $.229^{* *}$ & .021 \\
\hline & Sig & .000 & .000 & .000 & .000 & .000 & & .000 & .007 & .000 & .651 \\
\hline & $\mathrm{N}$ & 480 & 474 & 481 & 477 & 479 & 482 & 477 & 479 & 473 & 476 \\
\hline \multirow{3}{*}{$\begin{array}{l}\text { Tradi- } \\
\text { tion }\end{array}$} & Corr & $.547^{* *}$ & $.315^{* *}$ & $.384^{* *}$ & $268^{* * *}$ & $.133^{* *}$ & $.329^{* *}$ & 1 & $.410^{* *}$ & $.343^{* *}$ & $.314^{* *}$ \\
\hline & Sig & .000 & .000 & .000 & .000 & .004 & .000 & & .000 & .000 & .000 \\
\hline & $\mathrm{N}$ & 479 & 473 & 484 & 479 & 477 & 477 & 485 & 481 & 477 & 479 \\
\hline \multirow{3}{*}{$\begin{array}{l}\text { Secu- } \\
\text { rity }\end{array}$} & Corr & $.355^{* *}$ & $.204^{* * *}$ & $.226^{* *}$ & $.111^{*}$ & .057 & $.124^{* * *}$ & $.410^{* *}$ & 1 & $.264^{* *}$ & $.323^{* * *}$ \\
\hline & Sig & .000 & .000 & .000 & .015 & .214 & .007 & .000 & & .000 & .000 \\
\hline & $\mathrm{N}$ & 478 & 471 & 482 & 477 & 476 & 479 & 481 & 483 & 475 & 477 \\
\hline \multirow{3}{*}{$\begin{array}{l}\text { Hedo- } \\
\text { nism }\end{array}$} & Corr & $379^{* * *}$ & $.121^{* * *}$ & $236^{* *}$ & $.177^{* * *}$ & $.186^{* *}$ & $.229^{* *}$ & $.343^{* *}$ & $.264^{* *}$ & 1 & $.306^{* *}$ \\
\hline & Sig & .000 & .009 & .000 & .000 & .000 & .000 & .000 & .000 & & .000 \\
\hline & $\mathrm{N}$ & 473 & 468 & 478 & 473 & 471 & 473 & 477 & 475 & 479 & 473 \\
\hline \multirow{3}{*}{$\begin{array}{l}\text { Confor- } \\
\text { mity }\end{array}$} & Corr & $.195^{* *}$ & $.149^{* *}$ & $.121^{* *}$ & .051 & \begin{tabular}{l|l|}
-.007 \\
\end{tabular} & .021 & $314^{* *}$ & 479 & $.306^{* *}$ & 1 \\
\hline & Sig & .000 & .001 & .008 & .269 & .871 & .651 & .000 & $.323^{* *}$ & .000 & \\
\hline & $\mathrm{N}$ & 476 & 471 & 480 & 476 & 474 & 476 & 479 & .000 & 473 & 481 \\
\hline
\end{tabular}

Source: Own elaboration.

As seen in table 4, all correlations prove to be in the normal range below .5, except from the correlation between the values tradition and benevolence. In order to vanish any possibility of multicollinearity that might be affecting the significance of these factors in the final model, two actions were taken.

First, the principal components analysis was reviewed, to identify possible share loads among the components tradition and benevolence, finding no issue on this. Second, linear regressions 
were conducted individually between these factors and de dependent variable; the results confirmed that there are no statistical significance of benevolence and tradition over the entrepreneurial intention that may affect the final model results.

Once the factors were obtained through the reduction of dimensions and the results of the reliability analysis were calculated, the same treatment was carried out for the variables of entrepreneurial intention, the results of this factor analysis are presented below in Table 5.

TABLE 5. Matrix of components

\begin{tabular}{|c|l|}
\hline Component matrix & .880 \\
\hline IntencEmp1 & .910 \\
\hline IntencEmp2 & .945 \\
\hline IntencEmp3 & .938 \\
\hline IntencEmp4 & .925 \\
\hline IntencEmp5 & \\
\hline KMO $=.857$ & \\
\hline Significance $=.000$ & \\
\hline Cronbach's alfa $=.954$ & \\
\hline$\%$ of variance $=84.6 \%$ & \\
\hline
\end{tabular}

Source: Own elaboration.

Through the statistical treatment of the data obtained through the surveys for the factor Entrepreneurial Intention, the following results are obtained: the factor analysis yields a KMO sample adequacy indicator of .857 , which is considered a significant level (see Table 5). In the same factor analysis, the explained variance table was obtained, resulting in the data collected explaining up to 84.6 percent of the phenomenon (see Table 5).

The rotated components matrix of this same factor analysis shows the grouping of the five variables in a single factor corresponding to the entrepreneurial intention. The grouping is consistent with the theory since the extraction of components includes all the items included in the instrument to address the factor. 
Subsequently, the Cronbach's alpha was calculated to determine the reliability of the scale and an indicator of .954 was found for the five elements that make up the factor, which is shown in Table 5.

Once the factor analysis and measurement of reliability of the scales, a linear regression model was performed to determine the explicative capacity of each of the independent variables (personal values) on the dependent variable of the model (entrepreneurial intention) and the results are shown in Tables 6 and 7.

TABLE 6. Linear Regression Model Summary

\begin{tabular}{|l|l|l|l|l|}
\hline \multicolumn{4}{|c|}{ Summary } \\
\hline Model & R & R squared & R squared corrected & Typ. from an estimate \\
\hline 1 & $.786^{\text {to }}$ & .618 & .610 & .63122928 \\
\hline $\begin{array}{l}\text { a. Predictor variables: (Constant), Conformity, Benevolence, Stimulation, Safety, Self-Direction, Power, } \\
\text { Achievement, Hedonism, Tradition, Universalism } \\
\text { sig .000 }\end{array}$ \\
\hline
\end{tabular}

Source: Own elaboration.

TABLE 7. Coefficients and significance

\begin{tabular}{|l|l|c|c|c|}
\hline \multirow{4}{*}{ Model } & & $\begin{array}{c}\text { Typed } \\
\text { coefficients }\end{array}$ & & \\
\hline 1 & Beta & t & Sig. \\
\hline \multirow{1}{*}{} & (Constant) Entrepreneurial Intention & & & \\
\cline { 2 - 5 } & Benevolence & .038 & 1,292 & .197 \\
\cline { 2 - 5 } & Power & .108 & 3,66 & .000 \\
\cline { 2 - 5 } & Universalism & .160 & 5,371 & .000 \\
\cline { 2 - 5 } & Tradition & -.003 & -.091 & .927 \\
\cline { 2 - 5 } & Self-Direction & .084 & 2850 & .005 \\
\cline { 2 - 5 } & Achievement & .749 & 25288 & .000 \\
\cline { 2 - 5 } & Security & .005 & .176 & .860 \\
\cline { 2 - 5 } & Stimulation & .008 & .258 & 797 \\
\cline { 2 - 5 } & Hedonism & .078 & 2,64 & .009 \\
\cline { 2 - 5 } & Conformity & -.076 & -2539 & .011 \\
\hline
\end{tabular}

Source: Own elaboration.

In the results of the linear regression model, it is first seen that the model significant in general, presenting an index of sig .000 and offers an explicative capacity of .610 in the corrected $\mathrm{R}$ 
squared. This indicates that, in general, the proposed model of the subject's personal values, these explain up to $61 \%$ of the entrepreneurial intention factor.

When evaluating in detail the indicators of each factor in the model, it is found that there are four factors whose significance level, greater than .050 does not allow the results to be interpreted in a reliable way and these are: benevolence, tradition, safety, and stimulation. While the rest of the factors present reliable levels of significance to analyze their beta loads. Below is the model with the results obtained:

FIGURE 1. Model. Effect of personal values on entrepreneurial intention



Source: Own elaboration.

Once the linear regressions model has been carried out, the research equation is presented next:

$\mathbf{R}^{2} .610$ Entrepreneurial intention $=.108$ Power +.160 Universalism +.084 Self-direction + .749 Achievement +.078 Hedonism - .076 Conformity 


\section{Discussion and conclusions}

This research aims to evaluate which are the personal values that generate the greatest impact on the entrepreneurial intention of university students from CUCEA at the University of Guadalajara, Mexico. According to the most traditional theory of the personal characteristics of entrepreneurs, individual-oriented attitudes and personal characteristics have proven being positively associated with the entrepreneurial behavior (Tiessen 1997; Fitzsimmons and Douglas 2005; Baluku, Bantu and Otto 2018). Findings in this work demonstrate that those personal values associated to individual interests explain in a positive sense the intention to undertake of university students. All personal values categorized within the individualistic dimension of self-enhancement present a positive and significant effect on the entrepreneurial intention and this is perfectly lined-up with the literature, so hypotheses $1 \mathrm{~b}, 1 \mathrm{c}$ and $1 \mathrm{~d}$ are accepted. About personal values grouped within the individualistic dimension of openness to change, we identify that only self-direction shows a positive effect so hypothesis 1a is accepted, while stimulation resulted not significant so hypothesis 1e cannot be concluded. This result contrasts with different experiments in other countries where stimulation is commonly a strong predictor of entrepreneurial behavior or intention (Campos 2018; Liñan, Moriano and Jaén 2016).

Regarding the set of collectivist values we have some interesting results for some of them. For those personal values within the dimension of conservation, we find that security and tradition show no significance so hypotheses $2 \mathrm{a}$ and $2 \mathrm{c}$ cannot be concluded. However, the value conformity results significant and having a negative impact on the entrepreneurial intention, so hypothesis $2 \mathrm{e}$ is accepted, this means that respect for others and the possibility of hurt someone else are important issues to consider for students when think about becoming entrepreneurs. 
This is congruent with some part of the literature that present similar results (Zeffane 2014) and partially congruent with some other findings where this value result not even significant for entrepreneurial intentions (Alsaad 2018).

Analyzing personal values associated to the collectivist dimension of self-transcendence we identify that the value benevolence result not significant for the model so hypotheses $2 \mathrm{~d}$ is non conclusive. In the meantime, the value universalism proves to be significant and positively related to entrepreneurial intentions of university students; hypothesis $2 b$ is rejected. This is an interesting result due to the few literature supporting the idea of collectivism associated to entrepreneurial behavior. Previous work conducted by Alsaad (2018) or the same author of this research in different countries demonstrate that universalism relates negatively to the entrepreneurial intention or at least resulted not significant. In this sense, we assume that universalism, being a personal value strongly related to culture, may present different results across countries. It is also understood that the relatively recent appearance of social entrepreneurship also motivates students to visualize entrepreneurial projects with implications to the values associated to universalism.

In this research, universalism resulted to be the personal value with the second highest impact on the entrepreneurial intentions, only behind the value achievement. In this sense, we conclude as well that university students at the University of Guadalajara, have the personality to become either traditional or social entrepreneurs. (see Table 8)

TABLE 8. Personal values and their influence on entrepreneurial intention

\begin{tabular}{|l|l|l|c|l|l|}
\hline $\begin{array}{l}\text { Personal } \\
\text { value }\end{array}$ & Definition & Category & Impact & $\begin{array}{l}\text { Theory } \\
\text { contrast }\end{array}$ & Hypotheses \\
\hline Achievement & $\begin{array}{l}\text { Achievement } \\
\text { of economic } \\
\text { goals and }\end{array}$ & $\begin{array}{l}\text { Individualism/Self- } \\
\text { enhancement }\end{array}$ & .749 & $\begin{array}{l}\text { In accordance } \\
\text { with: (Jhonson }\end{array}$ & $\begin{array}{l}\text { 1a } \\
\text { Accepted }\end{array}$ \\
\hline
\end{tabular}




\section{Journal of Evolutionary Studies in Business}

\begin{tabular}{|c|c|c|c|c|c|}
\hline $\begin{array}{l}\text { Personal } \\
\text { value }\end{array}$ & Definition & Category & Impact & $\begin{array}{l}\text { Theory } \\
\text { contrast }\end{array}$ & Hypotheses \\
\hline & $\begin{array}{l}\text { desire to } \\
\text { improve the } \\
\text { current } \\
\text { economic } \\
\text { situation }\end{array}$ & & & $\begin{array}{l}\text { 1990; De Pillis } \\
\text { 1998) }\end{array}$ & \\
\hline Power & $\begin{array}{l}\text { Leadership } \\
\text { and } \\
\text { recognition of } \\
\text { other team } \\
\text { members }\end{array}$ & $\begin{array}{l}\text { Individualism/Self- } \\
\text { enhancement }\end{array}$ & .108 & $\begin{array}{l}\text { In accordance } \\
\text { with: } \\
\text { (Martinelli } \\
\text { 2004; } \\
\text { Zimmerman } \\
\text { 2014) }\end{array}$ & $\begin{array}{l}1 \mathrm{~b} \\
\text { Accepted }\end{array}$ \\
\hline Self-direction & $\begin{array}{l}\text { Independence } \\
\text { in decision- } \\
\text { making. } \\
\text { Setting own } \\
\text { goals and } \\
\text { ways of } \\
\text { behaving. Do } \\
\text { what it takes } \\
\text { to develop } \\
\text { and spread } \\
\text { your own } \\
\text { ideas }\end{array}$ & $\begin{array}{l}\text { Individualism/ } \\
\text { Openess to change }\end{array}$ & .084 & $\begin{array}{l}\text { In accordance } \\
\text { with: } \\
\text { (Noseleit 2010; } \\
\text { Liñan, Moriano } \\
\text { and Jaén 2016) }\end{array}$ & $\begin{array}{l}\text { 1c } \\
\text { Accepted }\end{array}$ \\
\hline Hedonism & $\begin{array}{l}\text { Pleasure and } \\
\text { sense of } \\
\text { gratification } \\
\text { for oneself }\end{array}$ & $\begin{array}{l}\text { Individualism/Self- } \\
\text { enhancement }\end{array}$ & .078 & $\begin{array}{l}\text { In accordance } \\
\text { with: (Halis, } \\
\text { Ozsabuncuoglu } \\
\text { and Ozsagir } \\
\text { 2007) } \\
\text { Not in } \\
\text { accordance } \\
\text { with: } \\
\text { (Alsaad 2018; } \\
\text { Campos 2018) }\end{array}$ & $\begin{array}{l}\text { 1d } \\
\text { Accepted }\end{array}$ \\
\hline Stimulation & $\begin{array}{l}\text { Inspired by } \\
\text { challenges, } \\
\text { satisfied by } \\
\text { working as a } \\
\text { team to the } \\
\text { limit of } \\
\text { abilities and } \\
\text { working at all } \\
\text { times with } \\
\text { enthusiasm }\end{array}$ & $\begin{array}{l}\text { Individualism/ } \\
\text { Openess to change }\end{array}$ & $\begin{array}{c}\text { Not } \\
\text { significant }\end{array}$ & & $\begin{array}{l}\text { le } \\
\text { Not } \\
\text { conclusive }\end{array}$ \\
\hline
\end{tabular}




\begin{tabular}{|c|c|c|c|c|c|}
\hline $\begin{array}{l}\text { Personal } \\
\text { value }\end{array}$ & Definition & Category & Impact & $\begin{array}{l}\text { Theory } \\
\text { contrast }\end{array}$ & Hypotheses \\
\hline Universalism & $\begin{array}{l}\text { A concern for } \\
\text { the economic } \\
\text { and political } \\
\text { situation of } \\
\text { the } \\
\text { community, a } \\
\text { commitment } \\
\text { to the } \\
\text { common good }\end{array}$ & $\begin{array}{l}\text { Collectivism/Self- } \\
\text { transcendence }\end{array}$ & .160 & $\begin{array}{l}\text { In accordance } \\
\text { with: (Zeffane } \\
\text { 2014) } \\
\text { Not in } \\
\text { accordance } \\
\text { with: (Alsaad } \\
\text { 2018; Campos } \\
\text { 2018) }\end{array}$ & $\begin{array}{l}2 \mathrm{~b} \\
\text { Rejected }\end{array}$ \\
\hline Conformity & $\begin{array}{l}\text { Restraint of } \\
\text { actions, } \\
\text { inclinations } \\
\text { and impulses } \\
\text { likely to harm } \\
\text { others and } \\
\text { violate social } \\
\text { norms }\end{array}$ & $\begin{array}{l}\text { Collectivism/ } \\
\text { Conservation }\end{array}$ & -.076 & $\begin{array}{l}\text { In accordance } \\
\text { with: (Zeffane } \\
\text { 2014) } \\
\text { Not in } \\
\text { accordance } \\
\text { with: (Alsaad } \\
\text { 2018) }\end{array}$ & $\begin{array}{l}2 \mathrm{e} \\
\text { Accepted }\end{array}$ \\
\hline Security & $\begin{array}{l}\text { Carry out } \\
\text { daily } \\
\text { activities in a } \\
\text { safe } \\
\text { environment, } \\
\text { free from any } \\
\text { type of threat. }\end{array}$ & $\begin{array}{l}\text { Collectivism/ } \\
\text { Conservation }\end{array}$ & $\begin{array}{c}\text { Not } \\
\text { significant }\end{array}$ & & $\begin{array}{l}\mathrm{a} \\
\text { Not } \\
\text { conclusive }\end{array}$ \\
\hline Tradition & $\begin{array}{l}\text { Respect, } \\
\text { commitment } \\
\text { and } \\
\text { acceptance of } \\
\text { customs, } \\
\text { culture and } \\
\text { ideas or } \\
\text { religion } \\
\text { provide, }\end{array}$ & $\begin{array}{l}\text { Collectivism/ } \\
\text { Conservation }\end{array}$ & $\begin{array}{c}\text { Not } \\
\text { significant }\end{array}$ & & $\begin{array}{l}2 \mathrm{c} \\
\text { Not } \\
\text { conclusive }\end{array}$ \\
\hline Benevolence & $\begin{array}{l}\text { Maintain } \\
\text { good } \\
\text { relationships } \\
\text { with those } \\
\text { who care and } \\
\text { are in frequent } \\
\text { contact. }\end{array}$ & $\begin{array}{l}\text { Collectivism/Self- } \\
\text { transcendence }\end{array}$ & $\begin{array}{c}\text { Not } \\
\text { significant }\end{array}$ & & $\begin{array}{l}2 \mathrm{~d} \\
\text { Not } \\
\text { conclusive }\end{array}$ \\
\hline
\end{tabular}

Source: Own elaboration with data from Gouveia (2003); Schwartz (1992); Ros and Grad (1991).

Although entrepreneurship is a phenomenon that has become popular in recent times for research, there are still lots of research to do in order to fully understand the factors involved in the process. This work includes a model that explains, through the classification of personal 
values, which of these influences a student's intention to start a business. This research is expected to contribute to scientific knowledge related to entrepreneurship as a social phenomenon.

This research constitutes a contribution to the few work carried out on entrepreneurship, particularly entrepreneurial intention and personal values. It is recommended that this model is used by other Higher Education Institutions as a tool to understand the orientation of the entrepreneurial attitude of students. Analyzing the personal values of students, an institution can design educational policy oriented to promote the type of entrepreneurship that fits the most the beliefs of the community.

Both traditional (commercial) entrepreneurship or social entrepreneurship are important drivers of economic and regional development (Hidalgo, Rialp and Urbano 2020). Analysis of personal values related to entrepreneurship my give a glance in the orientation of entrepreneurial education in higher education institutions. 


\section{References}

Ahmad Ahmadkhani, Leyla Heydari, M. Heydari, and Gholamreza Panahandeh. 2013. "Investigating the personal characteristics of entrepreneurs." Management Science Letters 3(11): 2717-724. doi: 10.5267/J.MSL.2013.10.007.

Alsaad, Abdallah. 2018. "The individualistic view of culture and the nascent entrepreneurship: an examination of schwartz's cultural values." Journal of Developmental Entrepreneurship 23(04): 1850026. doi: 10.1142/S1084946718500267.

Amit, Raphael, Kenneth R. MacCrimmon, Charlene Zietsma, and John M. Oesch. 2001. "Does money matter? Wealth attainment as the motive for initiating growth-oriented technology ventures". Journal of Business Venturing 16(2): 119-43. doi: 10.1016/S0883-9026(99)00044-0.

Anderson, Alistar R., and Sarah L. Jack. 2002. "The articulation of social capital in entrepreneurial networks: a glue or a lubricant?" Entrepreneurship and Regional Development 14(1): 193-10. doi: $10.1080 / 08985620110112079$.

Baluku, Martin Mabunda, Edward Bantu, and Kathleen Otto. 2018. "Effect of locus of control on entrepreneurial attitudes and self-employment intentions: the moderating role of individualism." Journal of enterprising culture 26(3): 251-83. 10.1142/S0218495818500103.

Bird, Barbara. 1988. "Implementing entrepreneurial ideas: The case for intentions", Academy of Management Review 13(3): 442-453.

Brandstätter, Hermann. 2011. "Personality aspects of entrepreneurship: A look at five meta-analyses." Personality and Individual Differences 51(3): 222-30. doi: 10.1016/j.paid.2010.07.007.

Brice, Jeff. 2004. "The role of personality dimensions on the formation of entrepreneurial intentions." USASBE Small Business Advancement National Center. Conway: University of Central Arkansas.

Bygrave, William D., and Charles W. Hofer. 1992. "Theorizing about Entrepreneurship". Entrepreneurship Theory and Practice, 16(2). 13-22. doi: 10.1177/2F104225879201600203.

Campos, Alejandro. 2018. The Role of Personal Values in the Entrepreneurial Process, México: ECOE Ediciones.

Chattopadhyay, Rachana, and Anil Kumar Ghosh. 2008. "Entrepreneurial intention model-based quantitative approach to estimate entrepreneurial success." Journal of Small Business and Entrepreneurship, 21(1): 1-21. doi: 10.1080/08276331.2008.10593410. 
Clemens, Christiane, and Maik Heinemann. 2006. "On the effects of redistribution on growth and entrepreneurial risk-taking." Journal of Economics 88(2): 131-158. doi: 10.1007/s00712-006$\underline{0191-9}$

De Pillis, Emmeline G. 1998. "What's Achievement Got to Do with it. The Role of National Culture in the Relationship Between Entrepreneurship and Achievement Motivation". Frontiers of entrepreneurship research, 73-87. http://fusionmx.babson.edu/entrep/fer/papers98/IV/IV_A/IV_A.html.

Dolan, Simon L., Salvador Garcia, and Bonnie Richley. 2006. Managing by values: A corporate guide to living, being alive and making a living in the 21st century. Basingstoke: Palgrave Macmillan.

Fagenson, Ellen A. 1993. "Personal value systems of men and women entrepreneurs versus managers." Journal of Business Venturing 8(5): 409-30. doi: 10.1016/0883-9026(93)90022-W.

Fayolle, Alain, Francisco Liñán, and Juan Antonio Moriano. 2014. "Beyond entrepreneurial intentions: values and motivations in entrepreneurship." International Entrepreneurship and Management Journal 10(4): 679-89. doi: 10.1007/s11365-014-0306-7.

Fitzsimmons, Jason R., and Evan J. Douglas. 2005. "Entrepreneurial attitudes and entrepreneurial intentions: a cross-cultural study of potential entrepreneurs in India, China, Thailand and Australia.” In Babson-Kauffman Entrepreneurial Research Conference. Wellesley.

Gartner, William B. 1988. "Who is an Entrepreneur? Is the wrong question." American Journal of Small Business 12(4): 11-32. doi: 10.1177/104225878801200401.

Gorgievsky, Marjan J, M. Evelina Ascalon, and Ute Stephan. 2011. "Small business owners' success criteria, a values approach to personal differences". Journal of Small Business Management 49(2): 207-32. doi: 10.1111/j.1540-627X.2011.00322.x.

Gouveia, Valdiney V. 2003. "A motivational nature of two human values: evidence about a new typology." Psychology Studies 8(3): 431-443. doi: 10.1590/S1413-294X2003000300010.

Halis, M., Ozsabuncuoglu, I. H., and Ozsagir, A. 2007. "The values of entrepreneurship and factors that effect entrepreneurship: Findings from Anatolia." Serbian Journal of Management 2(1): 21-34.

Hébert, Robert F., and Albert N. Link. 2006. "The entrepreneur as innovator." The Journal of Technology Transfer 31(5): 589-97. doi: 10.1007/s10961-006-9060-5.

Hidalgo, Luis. F., Josep Rialp, and David Urbano. 2020. “Are There Really Differences Between Social and Commercial Entrepreneurship in Developing Countries?: An Institutional Approach." In Handbook of Research on Smart Territories and Entrepreneurial Ecosystems for Social Innovation and Sustainable Growth, edited by Jesús Manuel Palma-Ruiz, José Manuel SaizÁlvarez, and Ángel Herrero-Crespo, 306-325. Hershey: IGI Global. 
Holland, Daniel V, and Dean A. Shepherd. 2013. "Deciding to Persist: Adversity, Values, and Entrepreneurs' Decision Policies". Entrepreneurship Theory and Practice 37(2): 331-58. doi: 10.1111/j.1540-6520.2011.00468.x.

Hormiga, Esther, Alejandro Campos Sánchez, and Jaume Valls Pasola. 2011. "ADICIONA: Una Empresa con Valor.” In Manual de Casos sobre Creación de Empresas en España, coordinated by José María Gómez Gras, 15-26. Madrid: McGraw-Hill.

Hornaday, John A., and John Aboud. 1971. "Characteristics of successful entrepreneurs." Personnel psychology 24(2): 141-53. doi: 10.1111/j.1744-6570.1971.tb02469.x.

Hueso, Juan A., Inmaculada Jaén, and Francisco Liñán. 2020. "From personal values to entrepreneurial intention: a systematic literature review." International Journal of Entrepreneurial Behavior and Research 27(1): 205-30. doi: 10.1108/IJEBR-06-2020-0383.

Hussin, Habrizah. 1997. "Personal values and identity structures of entrepreneurs: a comparative study of Malay and Chinese entrepreneurs in Malaysia." Entrepreneurship and SME research: On its way to the next millennium, edited by Rik Donckels and Asko Miettinen, 33-45. London and New York: Routledge.

Jaén, Inmaculada., Juan Antonio Moriano, and Francisco Liñán, Francisco. 2013. "Personal values and entrepreneurial intentions: An empirical study." Conceptual richness and methodological diversity in entrepreneurship research, edited by Alain Fayolle, Paula Kyrö, Tonis Mets and Urve Venesaar,15-31. Chentelham: Eward Elgar Publishing Limited

Johnson, Bradley R. 1990. "Toward a multidimensional model of entrepreneurship: The case of achievement motivation and the entrepreneur." Entrepreneurship Theory and practice 14(3): 3954. doi: $10.1177 / 104225879001400306$.

Krueger, Norris F., Michael Reily, and Alan L. Carsrud. 2000. "Competing models of entrepreneurial intentions." Journal of Business Venturing 15: 411-32. doi: 10.1016/S0883-9026(98)00033-0.

Kruse, Phillip., Dominika Wach, Sílvia Costa, and Juan Antonio Moriano. 2019. "Values matter, don’t they? - combining theory of planned behavior and personal values as predictors of social entrepreneurial intention." Journal of Social Entrepreneurship 10(1): 55-83. doi: 10.1080/19420676.2018.1541003.

Liñan, Francisco. 2008. "Skill and value perceptions: how do they affect entrepreneurial intentions?" International Entrepreneurship and Management Journal 4(3): 257-72. doi: 10.1007/s11365$\underline{008-0093-0 .}$

Liñán, Francisco., Juan Antonio Moriano, and Inmaculada Jaén. 2016. "Individualism and entrepreneurship: Does the pattern depend on the social context?" International Small Business Journal 34(6): 760-76. doi: 10.1177/0266242615584646. 
Liñan, Francisco., and Yi-Wen Chen. 2009. "Development and Cross-Cultural Application of a Specific Instrument to Measure Entrepreneurial Intentions." Entrepreneurship Theory and Practice. 33(3): 593-617. doi: 10.1111/j.1540-6520.2009.00318.x.

Lipset, Seymour Martin. 2000. "Values and entrepreneurship in the Americas." Entrepreneurship: The social science view, edited by Richard Swedberg, 110-128. Oxofrd: Oxford University Press.

Martinelli, Alberto. 2004. "The social and institutional context of entrepreneurship." Crossroads of entrepreneurship, edited by Guido Corbetta, Morton Huse and Davide Ravasi, 53-73. Dordecht: Kluwer Academic Publishers.

McKenna, Steve D. 1996. "The darker side of the entrepreneur." Leadership and Organization Development Journal 17(6): 41-45. doi: 10.1108/01437739610130519.

Morris, Michael H., Ramon A. Avila, and Jeffrey Allen. 1993. "Individualism and the modern corporation: Implications for innovation and entrepreneurship." Journal of management 19(3): 595-612. doi: 10.1177/014920639301900305.

Morris, Michael H, and Duane L. Davis. 1994. "Fostering corporate entrepreneurship: cross-cultural comparisons of the importance of individualism versus collectivism." Journal of International Business Studies 25(1): 65-89.

Mueller, Stephen L., and Anisya S. Thomas. 2001. "Culture and entrepreneurial potential: a ninecountry study of locus of control and innovativeness." Journal of Business Venturing 16(1), 5175. doi: 10.1016/S0883-9026(99)00039-7.

Mukherjee, Kaushal. 2016. "The psychology of the successful entrepreneur." International Journal of Advanced Engineering and Management 1(1): 25-32. doi: 10.24999/IJOAEM/01010004.

Noseleit, Florian. 2010. "The entrepreneurial culture: guiding principles of the self-employed." In Entrepreneurship and culture, edited by Andreas Freytag and Roy Thurik, 41-54. Berlin and Heidelberg: Springer. Doi: 10.1007/978-3-540-87910-7_3

Parker, Simon C. 2018. "Entrepreneurship and economic theory." Oxford Review of Economic Policy 34(4): 540-64. doi: 10.1093/oxrep/gry013.

Quadrini, Vincenzo. 2009. "Entrepreneurship in macroeconomics.” Annals of Finance 5(3-4): 295-311. doi: 10.1007/s10436-008-0105-7.

Romero, Ana. and Mónica Milone. 2016. "El emprendimiento en España: Intención emprendedora, motivaciones y obstáculos." Journal of Globalization, Competitiveness and Governability, 10(1): 95-109. doi: 10.3232/GCG.2016.V10.N1.05.

Ros, María, and Héctor M. Grad. 1991. "El significado del valor trabajo como relacionado a la experiencia ocupacional: Una comparación de profesores de EGB y estudiantes del CAP." Revista de Psicología Social, 6(2): 181-208. 
Rosa, Peter. and Allison Bowes. 1993. "Entrepreneurship: Some Lessons of Social Anthropology". In Entrepreneurship and Business Development, edited by Heinz Klandt. Farnham: Ashgate Publishing Limited.

Schwartz, Shalom H., Gila Melech, Arielle Lehmann, Steven Burgess, Mari Harris, and Vicki Owens. 2001. "Extending the Cross-Cultural Validity of the Theory of Basic Human Values with a Different Method of Measurement." Journal of Cross-Cultural Psychology, 32: 519-44. doi: 10.1177/0022022101032005001.

Schwartz, Shalom H. 1992. "Universals in the content and structure of values: Theoretical advance and empirical tests in 20 countries". Advances in Experimental Social Psychology, 25: 1-65. doi: 10.1016/S0065-2601(08)60281-6.

Schwartz, Salomon H. and Klaus Boehnke. 2004. "Evaluating the structure of human values with confirmatory factor analysis." Journal of research in personality 38(3): 230-55. doi: 10.1016/S0092-6566(03)00069-2.

Širec, Karin., and Dijana Močnik. 2012. "Gender specifics in entrepreneurs' personal characteristics." Journal of East European Management Studies 17(1): 11-39. doi: 10.5771/0949-6181-2012-111.

Soria, Karla., Sergio Zuñiga, and Sofia Ruiz. 2016. "Educación e intención emprendedora en estudiantes universitarios: Un estudio de caso." Formación Universitaria 9(1): 25-34. doi: 10.4067/S071850062016000100004.

Tiessen, James. H. 1997. "Individualism, collectivism, and entrepreneurship: A framework for international comparative research." Journal of Business Venturing 12(5): 367-84. doi: $\underline{10.1016 / \mathrm{S} 0883-9026(97) 81199-8 .}$.

Tomczyk, David., Junghyun Lee, and Erik Winslow. 2013. "Entrepreneurs' Personal Values, Compensation, and High Growth Firm Performance." Journal of Small Business Management 51(1): 66-82. doi: 10.1111/j.1540-627X.2012.00374.X.

Xie, Chuanyin. 2014. "Why Do Some People Choose to Become Entrepreneurs? An Integrative Approach.” Journal of Management Policy and Practice 15(1): 25.

Zeffane, Rachid. 2014. "Does collectivism necessarily negate the spirit of entrepreneurship?." International Journal of Entrepreneurial Behavior and Research 20(3): 278-96. doi: https://doi.org/10.1108/IJEBR-03-2013-0042.

Zhao, Hao, Scott E. Seibert, and G. Thomas Lumpkin. 2010. "The relationship of personality to entrepreneurial intentions and performance: A meta-analytic review." Journal of management 36(2): 381-404. doi: 10.1177/0149206309335187. 


\section{Journal of Evolutionary Studies in Business}

Volume 6, Number 2, 180-208, July-December 2021

doi.org/10.1344/jesb2021.1.j096

Zimmerman, John. 2014. "Toward a hypothesis connecting leadership and entrepreneurship." International Journal of Management and Information Systems 18(4): 291-98. 10.19030/ijmis.v18i4.8834.

This is an Open Access article distributed under the terms of the Creative Commons Attribution-Non-Commercial-No Derivatives License (http://creativecommons.org/licenses/by-nc-nd/4.0/), which permits non-comercial re-use and distribution, provided the original work is properly cited, and is not altered or transformed in any way. 